\title{
Cross-Sectional Survey of Relevant Literatures as to the Current Proposed Disease Mechanisms and Treatments of Amyotrophic Lateral Sclerosis (ALS)
}

\author{
Zachary Sanford, MS IV ${ }^{1}$
}

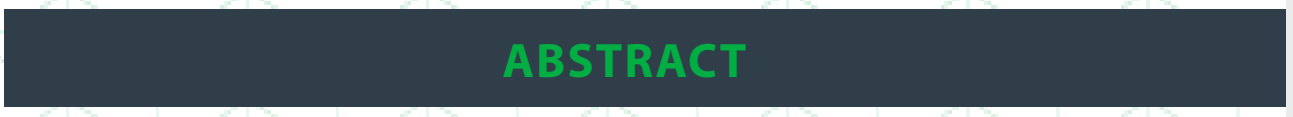

Amyotrophic Lateral Sclerosis (ALS), more commonly referred to as Lou Gehrig's disease, is a progressively degenerative neuromuscular disorder affecting both the upper and lower motor neurons and preferentially affecting males in their forties to seventies. Although the pathology of ALS has been clearly elucidated elsewhere, the precise mechanisms by which the disease progresses and the means by which it is acquired are still poorly understood areas of medicine. Current genomic and proteomic studies in human and animal models have yielded exciting and promising new findings that may help elucidate this pathology. It is the purpose of this review article to discuss the most relevant proposed mechanisms in current medical literature available from NCBI's PubMed database as well as to highlight past, present, and future pharmacologic intervention therapies which have experienced varying degrees of success. This is by no means an exhaustive assessment of the current literature available; however it should suffice as a thorough review of the most salient points of modern ALS research.
Author affiliations are listed at the end of this article.

Correspondence to: Zachary Sanford, MS IV Marshall University Joan C. Edwards School of Medicine sanford12@marshall.edu

\section{KEYWORDS}

ALS, Amyotrophic lateral sclerosis, mechanism, pathology, pharmacology

\section{INTRODUCTION}

Amyotrophic Lateral Sclerosis (ALS), more commonly referred to as Lou Gehrig's disease, is a progressively degenerative neuromuscular disorder affecting both the upper and lower motor neurons and preferentially affecting males in their forties to seventies. ${ }^{1,2}$ Disease pathogenesis selectively destroys upper motor neurons (UMN) of the primary motor cortex and corticospinal tracts in addition to lower motor neurons (LMN) of the spinal anterior horns and pontomedullary nuclei. ${ }^{3}$ The destruction of these motor neurons results in a loss of coordination for voluntary movement, often manifesting in a combination of UMN symptoms including muscle spasticity, hyperreflexia, increased deep tendon reflexes, and appearance of immature reflexes such as Babinski sign in conjunction with LMN symptoms such as progressive weakness, muscle hypotonia and atrophy, fasciculations, dysarthria, dysphagia and eventually respiratory failure. Of these symptoms, respiratory failure provides the greatest danger to the patient, with complications including secondary bacterial pneumonia compromising patients within two or three years of diagnosis. ${ }^{2}$ While the initial manifestation of these symptoms is seemingly random in distribution, disease progression often follows along contiguous neuroanatomic tracts to varying degrees of severity. The resulting UMN and LMN symptoms spread at differing rates and manifest as a consequence of complex somatotopy, creating complex motor phenotypes that are a hallmark of the disease. $^{4}$

The disease can further be subdivided into separate categories based on the method of inheritance or the location of symptom onset. ${ }^{1}$ ALS can present either sporadically (sporadic ALS, SALS) or along familial lines (Familial ALS, FALS) with a greater incidence of sporadic cases in the United States. ${ }^{1,2,5}$ Furthermore, symptoms of neurodegeneration can be first noticed either in the extremities (so-called extremity onset 
ALS) or the tongue (bulbar onset ALS). Extremity onset ALS is a degeneration of motor neurons enervating the arms or legs of afflicted individuals and can first include localized fasciculations, stiffness, and weakness. ${ }^{1}$ Patients with affected upper limbs will notice difficulty completing tasks that require manual dexterity whereas those with lower limb onset will notice irregularities in gate and a distinct dropped foot appearance. ' Disease progression is often less rapid in those presenting with extremity ALS than in bulbar cases. Those afflicted with bulbar onset ALS first notice difficulty speaking or swallowing, and symptoms quickly spread to the intercostal muscles and the diaphragm, ${ }^{1}$ posing serious respiratory risks that are the most frequent cause of death in ALS patients. ${ }^{2}$

\section{LACK OF CONSENSUS}

Presently there is a surprising lack of consensus among the medical community as to how to categorize familial versus sporadic ALS. ${ }^{5}$ In an international study among leaders in ALS research spanning Europe, India, Australia, and North America there were inconsistencies in how the distinction between the two categories were defined. While some felt the criterion for FALS should include firstdegree relatives including parents or siblings, others felt the need for second-degree (such as first or second cousins) or even any family relationship to warrant the title FALS. ${ }^{5}$ This distinction goes beyond nomenclature, as the protocols for diagnosing the two subfamilies differs substantially. When asked for comment, participating neurologists claimed to conduct screens for likely candidate genes implicated in ALS more frequently in FALS rather than SALS cases an overwhelming $67.0 \%$ to $10.3 \%$, respectively. ${ }^{5}$

Further complicating the situation is the lack of clear and agreed upon mechanisms of disease progression among the medical community. To date there have been over twelve loci and eight genes6 proposed as causative agents for FALS and among them exist hundreds of variations. Not surprisingly, the data available on such a diverse field of study is vast, with a literary search conducted on NCBI's PubMed database yielding close to 19,000 unique entries for amyotrophic lateral sclerosis. Searches were subsequently narrowed to include the terms "pathology" and "pharmacology," resulting in 1,034 results. Of these, entries were broadly selected to represent unique aspects of the body of literature as a whole. It is the purpose of this review article to therefore discuss the most relevant proposed mechanisms in current medical literature as well as to highlight pharmacologic interventional therapies with demonstrated or potential future success in treating ALS.

\section{SUGGESTIVE TRENDS IN DIAGNOSIS}

Among the difficulties in treating patients with ALS is quickly and effectively confirming a diagnosis while ruling out other possible disease processes. Effective clinical indicators are contested on the grounds of validity due to an incomplete understanding of the disease mechanism however firm agreement can be reached with regards to symptomology. For this reason, studies assessing the validity of measuring tongue strength as a prognosticator of bulbar onset ALS have yielded strong statistical significance. ${ }^{7}$ The effective use of this technique can help serve as a valuable tool in early, noninvasive detection of bulbar onset ALS rather than waiting for more advanced symptoms such as dysarthria and dysphagia which, once evidenced, are already severe enough to strongly affect patient survivability. Of the patients whose tongue strengths were assessed and who later developed ALS, a statistically significant proportion deteriorated quickly regardless of site of onset, indicating a rapid spread of lower motor neuron degeneration is best marked by assessment of tongue strength.,

On the other side of the clinical spectrum are highly advanced technologic measurements using functional Magnetic Resonance Imagery (fMRI) to assess neuronal activation as a function of disease progression. Interestingly, analysis of these techniques suggests there is an observable signal change in cortical blood oxygen levels during tasks requiring motor control of the hand specifically in ALS patients as measured against controls. ${ }^{9}$ These changes reflect a neuroplasticity heretofore unknown in ALS patients, although limited to those with slowly progressing disease 
symptomology and present only in initial phases of the disease. ${ }^{10}$ Still, these findings suggest either that slow disease progression affords patients the time to reorganize their own somatotopy or, conversely, that because patients are able to demonstrate efficient neuroplasticity they are able to delay the progression of the disease. ${ }^{9}$ Whichever the conclusion, the proven use of fMRI to assess these neuronal rearrangements proves promising for future study.

Not all advancements in the understanding of ALS have been noninvasive; attempts at isolating novel markers from cerebral spinal fluid (CSF) in order to obtain objective clinical markers for disease progression remain one of the forefronts of ALS research. Degeneration of the blood-CSF barrier is observed in $46 \%$ of ALS patients ${ }^{11}$ and offers a suggestive area of clinical assessment. Still, markers of blood brain barrier impairment, blood-spinal cord barrier impairment, blood-CSF barrier impairment, neuroaxonal degeneration, oxidative stress, neurotransmission, inflammation, immune activation, and glial activation have not yet yielded clinically relevant information in the diagnosis of ALS. ${ }^{11,12}$ While many of these markers are present in cases of ALS, they are not exclusive to this disease and have as yet presented a unique and reproducible clinical profile. However advancements have been made in other neurodegenerative diseases, with reductions in CSF CAMP and CGMP concentrations in Creutzfeldt-Jakob disease but not in ALS. ${ }^{12}$

\section{DISEASE MODELING}

Clinical presentations afford unique opportunities to track the progression of disease while occasionally affording the chance to test FDA-approved experimental drugs. However in the interest of discovery, safer, non-human models must be selected for study in order to fully elucidate disease mechanisms and assess pharmacologic intervention therapies. The gold standard in ALS research remains the SOD1-G93A transgenic mouse model for preclinical drug studies. G93A mice possess gainof-function mutations in the Superoxide Dismutase (SOD1) gene that enhances the generation of damaging oxygen radicals by $\mathrm{Cu}, \mathrm{Zn}$ Superoxide
Dismutase (Cu,Zn SOD). These mutations accurately reflect symptoms present in human FALS patients ${ }^{13-15}$ while also affording the luxury of working with a small, relatively short-lived animal model.

More recently, Pembroke Welsh Corgis and Boxers with mutations in SOD1 have been proven to illustrate degenerative myelopathy and peripheral neuropathy that can serve as a potential spontaneous model for human ALS. Homozygous silent mutations in canine SOD1:c.118 are able to recapitulate symptoms seen in the human disease process ${ }^{14}$ and can therefore offer superior alternatives to the murine model with regards to surgical study and evaluation of pharmacologic intervention. SOD mutants of the species Caenorhabditis elegans have also been generated for invertebrate study. C. elegans with pan-neuronal G85R SOD1 expression demonstrate significantly impaired locomotion and SOD1 aggregates characteristic of human FALS patients with SOD1 mutations. ${ }^{15}$ These invertebrate models offer cheaper alternatives to the higher order research animals and are free of many of the ethical concerns present when working with mammals. They are limited in their application, though, as the Federal Food and Drug Administration requires drug testing to be performed on mammals before reaching the public.

\section{PROPOSED MECHANISMS FOR ALS PATHOGENESIS}

Many of the proposed mechanisms currently under investigation focus on aberrations in neuronal transcription and translation events (Table 1). Irregularities in gene sequences either directly inherited or through predisposition to environmental insult, shift cellular machinery away from normal cellular chemistry toward dysfunctional proteins, hallmark cytosolic aggregations and plaques containing translationally inert RNA, and dysregulations in repair mechanisms. As no definitive etiology for ALS has been established, any or all of these mechanisms potentially represent processes in the pathology of disease and may contributes to a greater interwoven narrative. The following mechanisms are listed from most well-understood to the least elucidated although there is significant overlap in their purported functionality. 


\begin{tabular}{|c|c|c|c|c|}
\hline Gene Region & Normal Function & Aberrant Form & Associated Pathology & $\begin{array}{l}\text { ALS } \\
\text { Prevalence }\end{array}$ \\
\hline \multicolumn{5}{|l|}{ Aberrant RNA Binding Proteins } \\
\hline $\begin{array}{l}\text { Chromosome } 9 \text { Open Reading } \\
\text { Frame } 72 \text { (C9orf72) } \\
\text { Hexanucleotide Repeat Expansion }\end{array}$ & $\begin{array}{l}\text { 9p21 non-coding portion of } \\
C 9 \text { orf } 72\end{array}$ & $\begin{array}{l}\text { Hexanucleotide } \\
\text { GGGGCC expansion }\end{array}$ & $\begin{array}{l}\text { Downregulation of alternatively spliced } \\
\text { C9orf } 72 \text { transcript and formation of aberrant } \\
\text { nuclear RNA foci }\end{array}$ & $\begin{array}{l}40 \% \text { FALS } \\
7 \% \text { SALS }\end{array}$ \\
\hline $\begin{array}{l}\text { Transactive Response DNA- } \\
\text { Binding Protein of } 43 \mathrm{kDa}(T D P \text { - } \\
\text { 43) }\end{array}$ & $\begin{array}{l}\text { Transcriptional repression; } \\
\text { pre-mRNA splicing, } \\
\text { stabilizing, and transport; } \\
\text { translational regulation }\end{array}$ & $\begin{array}{l}\text { Silent mutations in } \\
342-366 \text { loci }\end{array}$ & $\begin{array}{l}\text { Alternate RNA splicing sites, aberrant } \\
\text { cytosolic aggregates }\end{array}$ & $\begin{array}{l}5 \% \text { FALS } \\
1 \% \text { SALS }\end{array}$ \\
\hline Fused in Sarcoma $(F U S)$ & $\begin{array}{l}\text { Presumed neuromuscular } \\
\text { junction functionality }\end{array}$ & $\begin{array}{l}\text { Numerous variations } \\
\text { in expression } \\
\text { (overexpression, } \\
\text { deletion) }\end{array}$ & $\begin{array}{l}\text { Disruptions in locomotion, abnormalities in } \\
\text { neuromuscular junction functionality }\end{array}$ & $\begin{array}{l}5 \% \text { FALS } \\
1 \% \text { SALS }\end{array}$ \\
\hline$A T A X I N 2$ CAG-Repeat & $\begin{array}{l}\text { mRNA translational and } \\
\text { stress response regulator }\end{array}$ & $>31$ CAG repeats & $\begin{array}{l}\text { Corresponding elongated polyglutamine } \\
\text { moieties }\end{array}$ & $\begin{array}{l}<1 \% \text { FALS } \\
5 \% \text { SALS }\end{array}$ \\
\hline $\begin{array}{l}\text { Ewing Sarcoma Breakpoint Region } \\
1 \text { (EWSRl) }\end{array}$ & $\begin{array}{l}\text { Putative transcriptional } \\
\text { repressor, RNA binding } \\
\text { protein }\end{array}$ & $\begin{array}{l}\text { Predicted C-terminal } \\
\text { prion domain }\end{array}$ & $\begin{array}{l}\text { Aberrant cytosol localization, prion-like } \\
\text { aggregation }\end{array}$ & $\begin{array}{l}\text { Unknown } \\
\text { FALS } \\
<1 \% \text { SALS }\end{array}$ \\
\hline \multicolumn{5}{|l|}{ Other Implicated Proteins } \\
\hline $\begin{array}{l}\mathrm{Cu} / \mathrm{Zn} \text { Superoxide Dismutase } 1 \\
(S O D I)\end{array}$ & $\begin{array}{l}\text { Destruction of superoxide } \\
\text { radicals }\end{array}$ & $\begin{array}{l}\text { apoSOD1 } \\
\text { (hyperoxidized } \\
\text { variant) }\end{array}$ & $\begin{array}{l}\text { Decreased O-glycosylation with } \beta-\mathrm{N}- \\
\text { Nacetylglucosamine (O-GlcNAc), alteration } \\
\text { in cellular phosphorylation, disruption of } \\
\text { zinc reserves and altered zinc homeostasis }\end{array}$ & $\begin{array}{l}20 \% \text { FALS } \\
3 \% \text { SALS }\end{array}$ \\
\hline Optineurin $(O P T N)$ & $\begin{array}{l}\text { Golgi complex exocytosis, } \\
\text { possible member of } \\
\text { TNF } \alpha / N F-\kappa B \text { signaling } \\
\text { pathway }\end{array}$ & $\begin{array}{l}\text { Novel deletions and } \\
\text { missense mutations in } \\
300 \text { bp Alu repeat } \\
\text { sequences }\end{array}$ & $\begin{array}{l}\text { Inhibition of endosomal recycling, } \\
\text { dysregulated control of cell death, abnormal } \\
\text { cytosolic inclusion bodies, absent inhibition } \\
\text { of NF-KB signaling pathway activation }\end{array}$ & $\begin{array}{l}<1 \% \text { FALS } \\
<1 \% \text { SALS }\end{array}$ \\
\hline $\begin{array}{l}\text { P56S Vesicle Associated membrane } \\
\text { Protein associated Protein B } \\
(V A P B)\end{array}$ & Sphingolipid metabolism & $\begin{array}{l}\text { Proline to serine } \\
\text { substitution }\end{array}$ & $\begin{array}{l}\text { Nuclear envelope deformity, irregularities in } \\
\text { nucleoporin and emerin delivery }\end{array}$ & $\begin{array}{l}<1 \% \text { FALS } \\
<1 \% \text { SALS }\end{array}$ \\
\hline
\end{tabular}

\section{TRANSACTIVE RESPONSE DNA-BINDING PROTEIN OF 43 KDA (TDP-43)}

TDP-43 is a nuclear nucleic acid binding protein primarily involved in RNA translational events and metabolism that when irregularly aggregated in the cytosol represents the major pathological finding in ALS cell studies. ${ }^{16-18}$ Pathologic accumulations demonstrate polyubiquination, hyperphosphorylation, and irregular cleavage that likely contributes to the abnormal localization in affected neurons. Once in the cytosol, mutant low molecular weight TDP-43 forms $\beta$-pleated sheets not consistent with wild type phenotype ${ }^{19}$ that are highly dependent on C-terminal domains demonstrating unusual stability and resistance to proteasome degradation. ${ }^{20}$ Granule accumulation is further promoted by microtubular dysfunction. ${ }^{21}$ Silent mutations in the 342-366 region affect RNA splicing regulation promoting the formation of stress granules whose exact function is as yet poorly understood. Current research as to whether these aggregates are protective or the hallmark of cellular damage are currently under investigation, as are studies to determine whether a loss of function or a gain of function mutation is responsible for this phenotype. What is known is that a polyubiquinated TDP-43 aggregate is present in 5\% of FALS and 0.5$2 \%$ of SALS cases. $^{22}$

Regional differences in composition of TDP43 stress granules between neuronal and glial intracytoplasmic inclusions in the spinal cord and medulla oblongata of SALS patients and those found in the basal ganglia and hippocampus indicate the possibility of heterogeneity in function or pathology depending on location in the central nervous system. Among these heterogeneities is the presence of Smurf2, an upstream effector of E3 ubiqitin ligase that may impact lower motor neuron function ${ }^{23}$ and studies suggesting TDP-43 operates independently of adenosine deaminase on RNA 2 (ADAR2). ${ }^{24}$

It has been implicated that other proteinaceous aggregates present during times of cellular strain serve as scaffolding for the formation of the cytosolic TDP-43 aggregates. ${ }^{25}$ These aggregates may follow a prion-disease-like pathology of replication, acting as an infectious transmissible protein species that behaves as a template for misfolding of nascent wild type proteins. ${ }^{19,26,27}$ This theory is further 
supported by the presence of described prionrelated glutamine/asparagine $(\mathrm{Q} / \mathrm{N})$ rich domain preferentially seen in prion disease and also expressed in proteins in ALS patients with mutant TDP-43. Introduction of these proteins in human embryonic kidney 293 (HEK293) cells was able to demonstrate prion seed-like behavior, serving as a template from which nascent wild type proteins misfolded to mutant conformations. ${ }^{19,28}$ Further studies in murine models with inducible cytosolic TDP-43 aggregates showed statistically significant correlation between increasing number of aggregates and ALS symptomatology, with a reversal of these symptoms seen on restoration of wild type TDP-43 function. ${ }^{29}$

Work in C. elegans models has suggested TDP-43 aggregates serve as a nidus for calcium-dependent neurodegeneration based on activation of killer aspartyl proteasomes. These models illustrate that reductions in intracellular calcium release, specifically via loss of function mutations in calreticulin, calnexin, or the ryanodine receptor or the introduction of intracellular calcium via ethylene glycol tetraacetic acid or dantroline are neuroprotective while increases in intracellular calcium via thapsigargin further exacerbate neurotoxicity. ${ }^{30}$ Other mouse studies mimicking nascent TDP-43 function in deficient cell lines was able to produce similar findings, with poly(A)binding protein nuclear 1 protein specifically demonstrating promising results. ${ }^{18,31}$

TDP-43 has been tentatively linked to a mechanism involving C9orf72 hexanucleotide expansion and Fus due to their involvement in RNA binding and transport $^{32}$ although these mechanisms are as yet poorly understood. Data co-localizing TDP43 with FUS aggregates and not with SOD1 has also been presented. ${ }^{21}$ Continued study into the pathogenesis of these aggregates is ongoing, 33,34 but is made more difficult with inconsistencies in the expected phenotypes of genotyped individuals. In a study by Mosca et al. two blood relatives with identical genotypes for the TDP-43 locus evidenced markedly different phenotypes; one sibling had severe onset ALS whereas the other (and the two other heterozygotes in the family) remained unaffected. ${ }^{35}$ Additionally, TDP-43 aggregates may not inherently be pathologic, having been located in adrenal medulla samples of individuals with and without ALS. ${ }^{36}$ Studies have begun elucidating the possibility that there are potential variations in TDP-43 conformations that can act as strains in pathogenesis with varying impact on cellular toxicity and disease pathogenicity. ${ }^{19}$

\section{CU/ZN SUPEROXIDE DISMUTASE 1 (SOD1)}

Mutant SOD1 proteins have been implicated in extracellular neuronal damage in a number of central nervous system diseases and are the traditional model for ALS disease progression. Intracellular damage is seen in clinical preparations however there is an equally likely mechanism depicting extracellular neuronal damage in mutant of SOD1 totaling over 140 variants. Studies have implicated that one of these variants, apoSOD1, undergoes abnormal folding to expose its zinc binding site, ${ }^{37}$ depleting cellular zinc stores and disrupting zinc homeostasis. In vitro studies have proven that apoSOD1 expression reduces viability of target cells but that this is not caused by the accumulation of cell aggregates as was seen in the RNA binding proteins listed previously. Further illustrating the zinc hypothesis are results showing abatement of cell destruction by the addition of exogenous zinc and exacerbation by the addition of known zinc chelators. ${ }^{38}$ These misfolded SOD1 mutants are increasingly becoming the target for drug therapy ${ }^{39}$ due primarily to their speculated early involvement in a thorough and complex oxidative damage cascade. Monoclonal antibody experiments targeting these abnormally folded SOD1 mutants ${ }^{40}$ have already been demonstrated in murine and human tissues.

The oxidative stress mechanism of nitrous oxide and other radical species put forth by proponents of the SOD1 theory of ALS pathogenesis are well documented in the literature ${ }^{41}$ and accommodates a wide variety of SOD1 mutants with an equally wide array of cellular effects. ${ }^{42}$ Among these varieties is a hyperoxidized variant of SOD1 found to be linked directly to certain cases of bulbar SALS ${ }^{43}$ as well as variants that resulted in decreased $\mathrm{O}$-glycosylation with $\beta$-N-Nacetylglucosamine (O-GlcNAc), an agent linked to competitive inhibition of cellular phosphorylation. ${ }^{44}$ The implication of this reduction in intracellular O-GlcNAc is a corresponding alteration 
in kinase activity which would cause highly irregular and cell-wide effects. Many of these mutants have phenotypic effects directly influenced by copy number of their aberrant proteins ${ }^{45}$ which are best assessed by RT-qPCR.

Similar to TDP-43 and its interrelatedness with Fus and C9orf72 hexanucleotide expansion, SOD1 mutations have been implicated in pathways with abnormal RNA binding proteins. Methodologies proposed by Pokrishevsky et al. purport TDP-43 or Fus aggregates in the cytosol facilitate wild type SOD1 conformational changes, forming new and unusual conformations. ${ }^{46}$ This mechanism mirrors the already established pattern of prion diseases, where a misfolded protein serves as a template for further misfoldings. ${ }^{47}$ This theory is generally accepted among the ALS community as a likely mechanism to explain SALS with SOD1 abnormalities. SOD has also been implicated as an intermediate in the ER damage cascade, with mutant SOD1 inappropriately utilizing PDI. ${ }^{48}$ To even further complicate the picture of a complete SOD1 cascade, fibroblast growth factor 2 deficiency prolonged survival and improved motor performance in ALS mouse models positive for mutant SOD1 protein. Accompanying this deficiency was an associated upregulation of glial derived neurotrophic factor and ciliary neurotrophic factor, two motor system-related neurotrophic factors. ${ }^{49}$

\section{FUSED IN SARCOMA (FUS)}

FUS is a nuclear RNA binding protein involved in transcription, post-translational modifications including RNA splicing and microRNA processing, and DNA repair. ${ }^{50-52}$ Aberrations in FUS also represent one of the primary hallmarks of ALS cellular pathology, identified in $4-6 \%$ of FALS and $0.7-1.8 \%$ SALS cases. ${ }^{53}$ These mutations result in a hyperosmolar cytosolic environment where localization of mutant aggregates can occur. ${ }^{51}$ These aggregates form stress granules similar to and occasionally co-expressed with TDP-43 and SOD1, where local RNA molecules play an as yet undetermined role in granule stability. ${ }^{54,55}$ Furthermore, FUS irregularities disrupt correct localization of RNA binding proteins, disrupting nuclear cellular events. ${ }^{56}$ One current theory posits the disruption in FUS localization prevents correct DNA damage repair, resulting in accumulation of injurious insults to motor neurons and culminating in stereotyped ALS symptomology. ${ }^{51}$ FUS mutants also express deficiencies in autoregulation, leading to an increased vulnerability to cellular stress and degeneration manifesting as axon withdrawal, synapse dysfunction, and muscular denervation. ${ }^{52}$

Animal models in Drosophila have demonstrated that mutations in FUS analog Cabeza (Caz) causes in vivo toxicity by disrupting neuromuscular junctions and inducing apoptosis in motor neurons. These effects are caused by a gain in function mutation resulting in overexpression of the gene, although these effects rely on the expression of the protein in the nucleus. Mutations in the Drosophila homolog Caz caused retinal degeneration, wing defects, decreased viability, but most importantly locomotive impairment in motor neurons and a disruption of presynaptic terminals at the neuromuscular junction culminating in motor neuron apoptosis. ${ }^{57}$ Toxicity is directly correlated to a functional C-terminus with overexpression as well as deletion resulting in similar disruptions of locomotion and neuromuscular junction abnormalities seen in human ALS patients. Apoptosis of motor neuron cell bodies was only observed in FUS overexpression models. ${ }^{57}$ C-terminal FUS knockout mice have corroborated the evidence for cytosolic aggregation seen in Drosophila but were unable to recreate ALS symptomatology. ${ }^{58}$ Additional murine models have been able to demonstrate neuroinflammation, denervation of neuromuscular junctions, reductions in functional dendritic cell architecture and total cell number, and premature host death when gain or loss of function mutations were introduced to FUS. ${ }^{59}$

Differences are observed in clinical models versus those seen in Drosophila, as variants in human FUS have been proven to signify endoplasmic reticular (ER) stress. Co-localization with ER markers was seen in human lumbar spinal cord sections taken from ALS patients. These markers include protein disulfideisomerase (PDI) as well as calreticulin, whose aggregates were seen with FUS in motor neuron cytosols, having translocated from the nucleus. These findings were consistent with both SALS as well as FALS and are related to the pathophysiology of SOD1 mutations. ${ }^{48}$ Patient-derived induced pluripotent 
stem cells transformed into spinal cord neural cells represent one model of FUS study, where stress granule aggregation has been correlated to volume of cytosolic mutant FUS concentrations. ${ }^{60}$ Utilizing similar models, DNA damage has been linked to cytoplasmic accumulations of mutant FUS mediated by phosphorylation of its $\mathrm{N}$ terminus by the DNAdependent protein kinase. ${ }^{61}$

In contrast to the models discussing aberrant cytosolic inclusion as a means for pathology, forced nuclear aggregation of FUS has been able to demonstrate neuronal cell death in some in vitro models. ${ }^{62}$ One study has isolated nuclear mutant FUS aggregates from ALS fibroblasts that proved resistant to sodium dodecyl sulfate denaturation, supporting the possibility that there are multiple ways to alter FUS functionality to cause neurodegeneration. ${ }^{56}$ Similar to TDP-43, FUs has also been implicated in prion disease-like pathology with FUS stress granules serving as proteinaceous templates for misfolding of nascent FUS proteins. ${ }^{63-66}$ This area of study is not yet fully explored and represents an ongoing area of research.

\section{CHROMOSOME 9 OPEN READING FRAME 72 (C9ORF72) HEXANUCLEOTIDE REPEAT EXPANSION}

Repeats of the hexanucleotide GGGGCC within the non-coding portion of C9orf72 on chromosome 9p21 have been reported to cause chromosome 9-linked FALS and frontotemporal dementia (FTD)67 and represent the most common genetic variant of ALS. ${ }^{68}$ In an international cross-sectional study evaluating 4448 ALS patients, $37 \%$ of individuals with FALS are in possession of this mutation, having as many as 700-1600 copies of the repeat sequence compared to controls who only have 23 copies. ${ }^{69}$ Comparable studies have been conducted in French (46\% FALS, 8\% SALS),70 Italian (46\% FALS),71 Greek (50\% FALS, 8.2\% SALS),72 Turkish (18.3\% FALS, 3.1\% SALS),73 Slavic (5.9\% SALS),74 and Russian (15\% FALS, 2.5\% SALS)75 populations testing positive for the GGGGCC repeat. Studies on Chinese SALS populations have yielded results indicating this sequence is not correlated to their patient populations, potentially describing a predilection for the C9orf72 hexanucleotide repeat for Caucasians. ${ }^{76,77}$

Phylogenetic analyses suggest that the hexanucleotide first originated in Finland, with all present day GGGGCC sequences in C9orf72 owing to a single mutation event 1500 years ago and representing $46.4 \%$ of FALS and $21.1 \%$ SALS of the Finnish population. ${ }^{69,78}$ The hexanucleotide repeat leads to the downregulation of the expression of an alternatively spliced C9orf72 transcript and to the formation of aberrant nuclear RNA foci. ${ }^{70}$ The increasing evidence for the presence of this sequence in FALS cases combined with the late age of onset for symptoms has led some studies to evaluate the possibility that this irregularity in RNA processing caused by the hexanucleotide expansion may be initially corrected by conventional cellular repair mechanisms only to eventually overwhelm the system in later life. ${ }^{79}$ This expansion itself may not be inherently irregular but instead trigger pathogenicity in differentially methylated states ${ }^{80,81}$ and has also demonstrated a concordance with abnormal localization of TDP-43, a hallmark of ALS neuronal pathology. ${ }^{68}$ Murine models with induced GGGGCC sequences have also been constructed, evidencing a gain of function relationship theorized elsewhere..$^{82,83}$

Although this sequence provides a possible marker for over one third of FALS cases, the ethical and moral implications of how to determine when patients should or should not be screened for this repeat are difficult at best to determine. The concerns about incomplete penetrance raised by Majounie et al. highlight an average age of disease onset of 57 with patients only beginning to have symptom onset well into their nineties. ${ }^{69}$ The exact determinants, if there are any, as to whether or not one should be screened for this repeat are as yet undetermined. ${ }^{84}$ Still, the screen can offer confirmation of disease in the event of a suspected diagnosis. Ongoing research into reproducible biomarkers of this region and novel therapeutic targets are a developing area of study. ${ }^{85}$

\section{P56S-VESICLE-ASSOCIATED MEMBRANE PROTEIN-ASSOCIATED PROTEIN B (VAPB)}

VAPB is a type Il integral membrane protein of the ER with the free $\mathrm{N}$ terminal region projecting into the 
cytosol and is involved in ER to Golgi transport as well as cellular stress response pathways. ${ }^{86-90}$ Murine models have illustrated loss of function mutations altering the unfolded protein response pathway, reducing functional myotubule formation ${ }^{91}$ and this model has been illustrated in human samples elsewhere. ${ }^{86,92}$ Additional murine studies have demonstrated progressive hyperactivity and motor impairment due to corticospinal and spinal motor neuron destruction in VABP transgenic mice. ${ }^{93}$ Autosomal dominant ALS based on a proline to serine substitution in the VAPB has been linked to nuclear envelope deformity, interrupting the transport of nucleoporin and emerin to the nuclear envelope. ${ }^{94}$ VABP has also been shown to suppress adipocyte lipid differentiation through alterations in mRNA expression, potentially altering energy metabolism in a subset of ALS patients. ${ }^{86}$ However, despite its involvement in intracellular transport, VABP mutations have not demonstrated alterations in protein transport or degradation. ${ }^{95}$ Of note, this mutation has not been demonstrated in SALS patients in Sweden, Portugal and Iceland. ${ }^{96}$

\section{OPTINEURIN (OPTN)}

OPTN is a protein involved in the nuclear factor kappa B (NF-KB) signaling pathway. Several mutations have demonstrated inhibited NF-KB activation and irregular localization of NF-KB proteins to neuronal and glial cytoplasm ${ }^{97,98}$ with a $300 \mathrm{bp}$ region consisting of Alu repeat sequences that are highly susceptible to novel deletions. Normal OPTN function has been shown to induce mitochondrial autophagolysosome formation and serves as an autophagy receptor, with mutations disrupting its ability to bind polyubiquinated proteins for transport to the lysosome for destruction. ${ }^{99-102}$ TDP-43 and SOD1 positive cells from SALS patients have also tested positive for OPTN mutations and suggest loss of function in OPTN as a contribution to TDP-43 accumulation. ${ }^{97,103-105}$ OPTN mutants are especially prevalent in the Japanese population, constituting the second most mutated gene product associated with SALS in Japan. ${ }^{106}$ In contrast, this mutation is exceptionally rare in British populations where it is deemed unlikely to be pathologic ${ }^{107}$ but can serve as a potential cause of rare rapidly progressive SALS in the Dutch. ${ }^{108}$

\section{EWING SARCOMA BREAKPOINT REGION 1 (EWSR1)}

EWSR1 is a RNA binding protein related to FUS and TDP-43 and a member of the FET protein family. Due to the fact that this protein is in possession of a predicted prion domain located on the C-terminus, it is prone to aggregate formation in both in vitro and in vivo specimens. It has been demonstrated to have a toxic effect when expressed ${ }^{109}$ and was proposed as an additional candidate for ALS pathogenesis. Histologic preparations of ALS spinal cord specimens illustrated aberrant localization in the cytosol of EWSR1 as opposed to the nucleus in healthy controls. ${ }^{109-111}$ One study presented 817 patients with ALS and 1082 healthy control individuals who tested positive for mutations in EWSR1 exons 1518 , the most pathogenic mutations in the gene region. ${ }^{109,112}$ Further work is being conducted evaluating the relevance of this protein.

\section{SPINOCEREBELLAR ATAXIA TYPE 2 PROTEIN (ATAXIN2)}

ATAXIN2 is another RNA binding protein potentially linked to ALS pathology, with moderate expansion of CAG polyglutamine sequences correlating to increased risk of ALS. ${ }^{113}$ Based on a cohort of 1538 ALS patients and controls in one Italian study, polyglutamine sequences that in excess of 31 amino acids place an individual at elevated risks for SALS compared to those lacking the repeat sequence. These trends did not hold true for FALS cases. ${ }^{114}$ This was also demonstrated in a cohort study of $375 \mathrm{ALS}$ patients of Sardinian ancestry with similar findings. ${ }^{115}$ Aberrant ATAXIN2 accumulations associate with TDP42 and FUS, altering their respective cellular toxicities and serving as components of cytosolic ALS stress granule formation. ${ }^{113}$

\section{EPIGENETICS AND ENVIRONMENT}

Recently, studies into the impact of environment on gene expression have yielded insight into the 
dynamic nature of transcriptional potential. Early life exposure, for example to in utero hypoxia, heavy metals, pesticides, tobacco, alcohol, or vitamin deficiency has been implicated as potential cause for changes in the genetic transcriptome. ${ }^{116-118}$ While the precise mechanisms by which such stressors can contribute specifically to ALS are as yet poorly understood, some promising studies have suggested specific methylation events on proteins such as Kir4.1 glial cell potassium channel by DNA methyltransferase may play a role in pathogenesis. ${ }^{119,120}$ Additionally, individuals with specific single nucleotide polymorphisms in the MT gene encoding metallothionein have demonstrated environmental susceptibility to acquiring ALS. ${ }^{16,121}$

\section{TREATMENTS AND INTERVENTIONS}

To date many studies have been conducted to determine which treatment interventions pose the greatest benefit to ALS morbidity and mortality. The following presents evidence for those methods that were strongly believed to be clinically significant, beginning with those that have demonstrable improvement on symptomatology and survival and continuing with interventions that may prove promising in the future, then concluding with several notable therapies that have not proven beneficial and should be avoided in the treatment of ALS (Table 2). Due to the chronic nature of this disease, each intervention is part of a broader scope of treatment delivered by neurologists, respiratory therapists, speechlanguage pathologists, physical therapists, dieticians, social workers, psychiatrists, nurses, and other allied health professionals.

\section{BI-LEVEL INTERMITTENT POSITIVE PRESSURE (BIPAP)}

Due to the current limited understanding of the full mechanism of disease progression in ALS, the most important treatment to date remains the effective administration of assisted respiratory technologies. Of these, the most useful and well-documented in the literature is the use of bi-level intermittent positive pressure (BiPAP) as an effective, noninvasive, and generally well-tolerated means of ensuring gas exchange. In a retrospective study conducted at Hahnemann Hospital, Kleopa et al. evaluated the efficacy of BiPAP intervention on patient outcomes and noted significant success in prolonging lifespan and decreasing symptom onset in ALS patient populations. Furthermore, the clinic suggests that patients receive a recommendation for BiPAP during the first clinical visit where the Forced Vital Capacity (FVC) reaches $50 \%$ of the expected normal. When used for four hours a day or longer, BiPAP helped increase survival by 14.2 months. ${ }^{122}$

\begin{tabular}{|c|c|}
\hline Intervention & Impact on ALS Symptomatology \\
\hline \multicolumn{2}{|c|}{ POSITIVE INTERVENTIONS } \\
\hline $\begin{array}{l}\text { Bi-Level Intermittent } \\
\text { Positive Pressure } \\
\text { (BiPAP) }\end{array}$ & $\begin{array}{l}\text { Definitive, part of gold standard of treatment. Demonstrated } \\
\text { prolonging lifespan and decreased symptom onset. Increase in mean } \\
\text { survival by } 14.2 \text { months when used for four hours per day when } \\
\text { FVC reaches } 50 \% \text { expected normal. }\end{array}$ \\
\hline Riluzole & $\begin{array}{l}\text { FDA approved for treatment of ALS. Neuroprotective, blocks CNS } \\
\text { glutaminergic transmission though mechanism is still debated. } 100 \\
\text { mg daily dosing has increased one year survival } 9 \% \text { and increased } \\
\text { mean survival by } 3 \text { months. }\end{array}$ \\
\hline Resistance Exercise & $\begin{array}{l}\text { Equivocal improvements in upper and lower extremity strength and } \\
\text { quality of life measures. }\end{array}$ \\
\hline \multicolumn{2}{|c|}{ PROMISING INTERVENTIONS } \\
\hline Arimoclomol & $\begin{array}{l}\text { Experimental. Presumed upregulation of heat shock factor-1 } \\
\text { resulting in correct SOD-1 folding. }\end{array}$ \\
\hline Ghrelin & $\begin{array}{l}\text { Limited studies have shown exposure in vitro block TNF } \alpha \text { and IL-1 } \beta \\
\text { expression, possibly promoting motor neuron survival. }\end{array}$ \\
\hline Botox & $\begin{array}{l}\text { Clinical trials have shown decreases in upper esophageal sphincter } \\
\text { hyperactivity and sialorrhea. }\end{array}$ \\
\hline $\begin{array}{l}\text { Dextromethorphan with } \\
\text { Quindine }\end{array}$ & $\begin{array}{l}\text { Phase I improvement in peduobulbar affect, not FDA approved for } \\
\text { this use. }\end{array}$ \\
\hline \multicolumn{2}{|c|}{ FAILED INTERVENTIONS } \\
\hline Nimodipine & $\begin{array}{l}\text { Calcium channel blocker proven to be ineffective in managing ALS } \\
\text { symptoms in double blind study. }\end{array}$ \\
\hline Coenzyme Q10 (CoQ10) & $\begin{array}{l}\text { Speculated to counteract oxidative damage resulting in SOD mutant } \\
\text { ALS due to role as mitochondrial antioxidant cofactor. Failed to } \\
\text { demonstrate benefit in Phase II trials. }\end{array}$ \\
\hline Lithium & $\begin{array}{l}\text { Failed phase III multicenter double-blinded randomized control } \\
\text { study, no discernible benefit to ALS patients. }\end{array}$ \\
\hline Minocycline & $\begin{array}{l}\text { Failed phase III multicenter double-blinded randomized control } \\
\text { study, demonstrable harm illustrated for ALS patients. }\end{array}$ \\
\hline Erythropoietin & $\begin{array}{l}\text { Failed phase III multicenter double-blinded randomized control } \\
\text { study, no discernible benefit to ALS patients. }\end{array}$ \\
\hline
\end{tabular}

mds.marshall.edu/mjm

(c) 2022 Marshall Journal of Medicine
Marshall Journal of Medicine

Volume 1 Issue 1 


\section{RILUZOLE}

Currently there is only one FDA-approved drug for the treatment of symptoms in ALS patients. This drug, Riluzole, is a neuroprotective drug that blocks glutamatergic neurotransmission in the CNS. It has been proven to inhibit the release of glutamic acid in vitro and in vivo, though the mechanism is still speculated and assumed to be due to inactivation of voltage-dependent sodium channels on glutamatergic nerve terminals or possibly the result of a G-protein coupled receptor cascade. Riluzole also blocks some of the postsynaptic effects of glutamic acid by noncompetitive blockade of $\mathrm{N}$-methyl-D-aspartate (NMDA) receptors. The drug is generally accepted to be a neuroprotectant with strong anticonvulsant albeit sedative properties. ${ }^{123}$ In clinical trials, $100 \mathrm{mg}$ daily dose of Riluzole was able to demonstrate a $9 \%$ gain in probability of surviving one year over control and raised median survival from 11.8 to 14.8 months. There was also modest symptom improvement in both bulbar and extremity onset ALS. ${ }^{124}$

\section{DEXTROMETHORPHAN WITH ULTRA LOW-DOSE QUINIDINE (NUEDEXTA ${ }^{\circledR}$ )}

Psuedobulbar affect is a prominent complaint among patients with ALS, prompting studies to be completed on the potential benefits of dextromethorphan. As a selective, noncompetitive antagonist of the N-methyl-D-aspartate subtype of the glutamate receptor studies initially attempted to determine if ALS symptomatology would be reduced although results showed no measurable decrease in rate of disease progression. ${ }^{125,126}$ In conjunction with ultra low dose quinidine to prevent rapid metabolism of dextromethorphan, Phase I studies have demonstrated improvement in peduobulbar affect. The most common side effects while taking $20 \mathrm{mg}$ dextromethorphan and $10 \mathrm{mg}$ quinidine although mild included light-headedness, slurred speech, and fatigue. ${ }^{127-129}$ Presently long term safety data is lacking. ${ }^{130,131}$ Due to difficulties extrapolating data from small sample sizes, this therapy is not yet FDA approved.

\section{BOTULINUM TOXIN (BOTOX ${ }^{\circledR}$ )}

Botulinum toxin is a paralytic toxin that interferes with neural transmission by blocking release of acetylcholine, thus promoting muscle paralysis. In ALS patients suffering from upper esophageal sphincter hyperactivity and sialorrhea small clinical trials have demonstrated measurable increases in quality of life outcomes through botulinum administration. ${ }^{132-134}$ Specifically, patients with UES hyperactivity experienced decreases in dysphagia for up to four weeks ${ }^{132}$ while sialorrhea was reduced for up to two months. ${ }^{133}$

\section{RESISTANCE EXERCISE}

With muscle weakness representing a significant cause of morbidity in ALS patients, surprisingly little objective data has been compiled on the effectiveness of resistance training in improving patient quality of life. Data remains largely equivocal due to existing cohort studies assessing small numbers of patients, but what data does exist is promising. One random controlled study determined improvement based on increased total ALS Functional Rating Scale as well as increases in upper and lower limb functionality and has been corroborated by studies undertaken in Canada. ${ }^{135-137}$ This is a promising area of study that will hopefully be developed more fully in the future.

\section{ARIMOCLOMOL}

Arimoclomol is an experimental research drug that amplifies heat shock protein gene expression during cell stress and has also been useful in prolonging the lifespan of SOD1 mutant mice. Although its exact mechanisms are poorly understood, it is assumed that Arimoclomol amplifies the active phosphorylated trimer of the transcription factor, heat shock factor-1. This could potentially increase available heat shock proteins to help chaperone the correct folding patterns in mutant SOD1 proteins. ${ }^{138}$ Efficacy studies are as yet unpublished for patients but the drug has proven to be well-tolerated and 
safe for human consumption at doses up to $300 \mathrm{mg} /$ day with evidence strongly supporting the drug be dosed three times daily. ${ }^{139}$

\section{GHRELIN}

Studies from a Korean research team have recently begun utilizing ghrelin as a potential therapeutic treatment for ALS, based on the protective effect ghrelin has on motor neurons experiencing chronic glutamate excitotoxicity. Ghrelin has been implicated in the activation of extracellular signal-regulated kinase $1 / 2$ and phosphatidylinositol-3-kinase/Akt/ glycogen synthase kinase- $3 \beta$ pathways. In order to confirm ghrelin's direct involvement in these cascades, spinal cord cultures were exposed to exogenous threohydroxyaspartate for three weeks in order to cause motor neuron degeneration. After this interval, application of ghrelin was able to significantly attenuate this degeneration. Ghrelin was also useful in preventing the expression of pro-inflammatory cytokines tumor necrosis factor- $\alpha$ and interleukin- $1 \beta$, common factors in neurodegenerative inflammatory processes. From these studies, it is proposed that ghrelin is acting as a microglia deactivating factor, promoting the survival of distressed motor neurons. ${ }^{140}$

\section{NIMODIPINE}

Nimodipine is a calcium channel blocker unsuccessful in the therapeutic treatment of ALS that was theorized to potentially antagonize excitatory amino acid receptor activation, decrease calcium entry into damaged neurons, and slow or perhaps reverse ALS. Unfortunately in a randomized, placebocontrolled, prospective, double-blind crossover study of nimodipine therapy there was no statistical significance in the rate of decline of pulmonary function or limb strength during treatment compared to control. Additionally, subjects receiving nimodipine experienced associated side effects including diarrhea, nausea, and lightheadedness. ${ }^{141}$ Researchers have abandoned this drug in ALS treatment and management at the clinical trial level, however one model utilizing SOD1(G37R) mice included nimodipine as part of a cocktail including minocycline and riluzole and was able to demonstrate significant delay in symptom onset, preservation in muscle strength, and increased longevity. ${ }^{142}$

\section{COENZYME Q10 (COQ10)}

CoQ10 is an antioxidant and mitochondrial cofactor and as such serves as a promising pharmacologic intervention. SOD1 mutants suffer from oxidative damage, suggesting the addition of an antioxidant may improve the clinical scenario at least slightly, and the mitochondrial damage seen in some ALS specimens offered further hope that additional mitochondrial factors would abate symptoms. However, during Phase II testing 2,700 mg were administered daily for nine months and showed no statistically significant reason to continue on to Phase III testing. There were no observed side effects in the patient population taking CoQ10, however there were no observable benefits, either. ${ }^{143}$

\section{LITHIUM}

Lithium is a monovalent ion that chemically competes with magnesium to alter activity of glycogen synthase kinase-3 beta, inositol monophosphatase, and Akt/ $\beta$-arrestin2. It represented a potential candidate drug for ALS disease modification due to its effects on cellular oxidative stress, inflammatory pathways, autophagy and neurotrophism. ${ }^{144}$ A trial study in 2008 ignited interest in lithium research for ALS when functional deterioration was markedly reduced in a cohort of 16 patients over a fifteen month timeframe. However meta-analysis of 1100 ALS patients using lithium was unable to reproduce these findings. ${ }^{145}$ Phase Ilb randomized trials on 67 patients and a phase III multicenter double-blinded randomized control study was concluded in 2011 that also was unable to demonstrate any significant benefit on survival outcomes. ${ }^{146,147}$ Although clinical trials have heavily supported the notion that lithium is no longer a viable research prospect for the treatment of ALS, recent studies have demonstrated that co-administration of riluzole may potentially mask potential neuroprotective effects of additional compounds, including lithium which in one trial was able to reduce ALS neurotoxicity. ${ }^{148}$ 


\section{MINOCYCLINE}

Minocycline is a member of the tetracycline class of antibiotics that has demonstrated potential neuroprotective effects as a result of its specific anti-inflammatory mechanisms and regulation of apoptosis pathways. ${ }^{149,150}$ After safety trials were established for patient use along with riluzole, clinical trials were initiated and early magnetic resonance imaging of patients on minocycline showed chemical changes in the precentral gyrus and brainstem in ALS patients. ${ }^{151,152}$ A phase III multicenter double-blinded randomized control study was completed in 2007 studying 412 ALS patients who were administered $400 \mathrm{mg}$ minocycline daily. The results indicated minocycline was actually harmful to patients, conferring no beneficial effect for ALS morbidity or mortality while reducing quality of life. ${ }^{153,154}$

\section{ERYTHROPOIETIN}

Erythropoietin (EPO) is a hormone responsible for regulation of red blood cell production and was studied in murine models as a potential disease modifying agent for ALS, initially improving motor function and prolonging symptom onset in a dosedependent fashion. ${ }^{155-157}$ CSF studies revealed lower EPO concentrations in ALS patients compared to controls, prompting research into potential efficacy trials. ${ }^{158}$ Although safe and well-tolerated initial studies and suggesting potential reductions in neurodegeneration, a phase III multicenter doubleblinded randomized control study of 208 patients was unable to demonstrate change in the course of ALS pathology. ${ }^{159-161}$

\section{FUTURE WORK}

At present there exists no cure or long-term treatment regimen for ALS. Lifespans are lengthened on an order of months with the most optimistic of therapies and the mechanism of disease pathogenesis at the cellular level is poorly understood. Promising studies on the use of autologous bone marrow mononuclear cells ${ }^{162}$ have been proven to reduce TDP-43 aggregations in limited study populations and lumbar intraspinal injection of neural stem cells ${ }^{163}$ have proven safe for continued Phase II research but as yet show no motor neuron protection. In addition to such exciting findings there are also disheartening discoveries still in their infancy. One proposed explanation for the failures of pharmacologic therapy has been an upregulation of $A B C$ drug transporter proteins such as P-glycoprotein (P-gp) and breast cancer resistance protein (BCRP) both at mRNA and protein levels as seen in the SOD1-G93A mouse model. ${ }^{164}$ This research clearly illustrates that a cellular resistance mechanism is being utilized to some degree and presents its own set of unique challenges in future treatment strategies.

\section{CONCLUSION}

This has been an attempt at summarizing the most significant findings found presently in the literature regarding ALS disease progression, mechanism, and treatment. With the rapidly advancing rate of clinical trials and cytologic analysis there will invariably be discoveries that contribute to and potentially contradict many of the mechanisms proposed. At present the stress granule theory implicating the RNA binding proteins TDP-43, SOD1, and FUS are the most heavily implicated in ALS cellular pathology and riluzole is the only FDA approved pharmacologic intervention proven effective for disease modification and increased quality of life. Non-pharmacologic interventions such as physical therapy and BiPAP still present useful adjuncts to therapy and should be considered when treating ALS patients. As research continues to find new and more effective methods of treating ALS, these cellular pathways will become better known and serve as the foundation for improved therapies and increased survival for patients in the future.

\section{AUTHOR AFFILIATIONS}

1. Marshall University Joan C. Edwards School of Medicine, Huntington, WV 25701 


\section{REFERENCES}

1. Baumann F, Henderson RD, Gareth Ridall P, Pettitt AN, McCombe PA. Quantitative studies of lower motor neuron degeneration in amyotrophic lateral sclerosis: evidence for exponential decay of motor unit numbers and greatest rate of loss at the site of onset. Clinical neurophysiology: official journal of the International Federation of Clinical Neurophysiology. 2012;123(10):2092-8.

2. Rowland LP. Amyotrophic lateral sclerosis: theories and therapies. Annals of neurology. 1994;35(2):129-30.

3. Turner MR, Verstraete $E$. What does imaging reveal about the pathology of amyotrophic lateral sclerosis? Current neurology and neuroscience reports. 2015;15(7):45.

4. Ravits JM, La Spada AR. ALS motor phenotype heterogeneity, focality, and spread: deconstructing motor neuron degeneration. Neurology. 2009;73(10):805-11.

5. Byrne S, Elamin M, Bede P, Hardiman O. Absence of consensus in diagnostic criteria for familial neurodegenerative diseases. Journal of neurology, neurosurgery, and psychiatry. 2012;83(4):365-7.

6. Kwee LC, Liu Y, Haynes C, Gibson JR, Stone A, Schichman SA, et al. A high-density genomewide association screen of sporadic ALS in US veterans. PloS one. 2012;7(3):e32768.

7. Weikamp JG, Schelhaas HJ, Hendriks JC, de Swart BJ, Geurts AC. Prognostic value of decreased tongue strength on survival time in patients with amyotrophic lateral sclerosis. Journal of neurology. 2012;259(11):2360-5.

8. Fujimura-Kiyono C, Kimura F, Ishida S, Nakajima $H$, Hosokawa $T$, Sugino $M$, et al. Onset and spreading patterns of lower motor neuron involvements predict survival in sporadic amyotrophic lateral sclerosis. Journal of neurology, neurosurgery, and psychiatry. 2011;82(11):1244-9.

9. Poujois A, Schneider FC, Faillenot I, Camdessanche JP, Vandenberghe N, ThomasAnterion C, et al. Brain plasticity in the motor network is correlated with disease progression in amyotrophic lateral sclerosis. Human brain mapping. 2013;34(10):2391-401.

10. Mohammadi B, Kollewe K, Samii A, Dengler $\mathrm{R}$, Munte TF. Functional neuroimaging at different disease stages reveals distinct phases of neuroplastic changes in amyotrophic lateral sclerosis. Human brain mapping. 2011;32(5):7508.

11. Tarasiuk J, Kulakowska A, Drozdowski W, Kornhuber J, Lewczuk P. CSF markers in amyotrophic lateral sclerosis. Journal of neural transmission. 2012;119(7):747-57.

12. Oeckl $P$, Steinacker $P$, Lehnert $S$, Jesse $S$, Kretzschmar HA, Ludolph AC, et al. CSF concentrations of CAMP and CGMP are lower in patients with Creutzfeldt-Jakob disease but not Parkinson's disease and amyotrophic lateral sclerosis. PloS one. 2012;7(3):e32664.

13. Gurney ME. The use of transgenic mouse models of amyotrophic lateral sclerosis in preclinical drug studies. Journal of the neurological sciences. 1997;152 Suppl 1:S67-73.

14. Shelton GD, Johnson GC, O'Brien DP, Katz $\mathrm{ML}$, Pesayco JP, Chang BJ, et al. Degenerative myelopathy associated with a missense mutation in the superoxide dismutase 1 (SOD1) gene progresses to peripheral neuropathy in Pembroke Welsh corgis and boxers. Journal of the neurological sciences. 2012;318(1-2):55-64.

15. Boccitto M, Lamitina T, Kalb RG. Daf-2 signaling modifies mutant SOD1 toxicity in C. elegans. PloS one. 2012;7(3):e33494.

16. Stalekar M, Yin X, Rebolj K, Darovic S, Troakes $C$, Mayr $M$, et al. Proteomic analyses reveal that loss of TDP-43 affects RNA processing and intracellular transport. Neuroscience. 2015;293:157-70.

17. Chang XL, Tan MS, Tan L, Yu JT. The Role of TDP-43 in Alzheimer's Disease. Molecular neurobiology. 2015.

18. Ling JP, Pletnikova O, Troncoso JC, Wong PC. NEURODEGENERATION. TDP-43 repression of nonconserved cryptic exons is compromised in ALS-FTD. Science. 2015;349(6248):650-5.

19. Smethurst P, Sidle KC, Hardy J. Review: Prion-like mechanisms of transactive response DNA binding protein of $43 \mathrm{kDa}$ (TDP-43) in amyotrophic lateral sclerosis (ALS). Neuropathology and applied neurobiology. 2015;41(5):578-97.

20. Liu Y, Duan W, Guo Y, Li Z, Han H, Zhang S, et al. A new cellular model of pathological TDP-43: The neurotoxicity of stably expressed CTF25 of TDP43 depends on the proteasome. Neuroscience. 2014;281C:88-98. 
21. Farrawell NE, Lambert-Smith IA, Warraich ST, Blair IP, Saunders DN, Hatters DM, et al. Distinct partitioning of ALS associated TDP-43, FUS and SOD1 mutants into cellular inclusions. Scientific reports. 2015;5:13416.

22. Budini M, Romano V, Avendano-Vazquez SE, Bembich S, Buratti E, Baralle FE. Role of selected mutations in the $\mathrm{Q} / \mathrm{N}$ rich region of TDP-43 in EGFP-12xQ/N-induced aggregate formation. Brain research. 2012;1462:139-50.

23. Nakamura M, Kaneko S, Wate R, Asayama S, Nakamura Y, Fujita K, et al. Regionally different immunoreactivity for Smurf2 and pSmad $2 / 3$ in TDP-43-positive inclusions of amyotrophic lateral sclerosis. Neuropathology and applied neurobiology. 2013;39(2):144-56.

24. Yamashita T, Hideyama T, Teramoto S, Kwak S. The abnormal processing of TDP-43 is not an upstream event of reduced ADAR2 activity in ALS motor neurons. Neuroscience research. 2012;73(2):153-60.

25. Dewey CM, Cenik B, Sephton CF, Johnson BA, Herz J, Yu G. TDP-43 aggregation in neurodegeneration: are stress granules the key? Brain research. 2012;1462:16-25.

26. Ludolph AC, Brettschneider J. TDP-43 in amyotrophic lateral sclerosis - is it a prion disease? European journal of neurology : the official journal of the European Federation of Neurological Societies. 2015;22(5):753-61.

27. Grad LI, Fernando SM, Cashman NR. From molecule to molecule and cell to cell: prion-like mechanisms in amyotrophic lateral sclerosis. Neurobiology of disease. 2015;77:257-65.

28. Furukawa Y, Kaneko K, Watanabe S, Yamanaka $K$, Nukina N. A seeding reaction recapitulates intracellular formation of Sarkosyl-insoluble transactivation response element (TAR) DNAbinding protein-43 inclusions. The Journal of biological chemistry. 2011;286(21):18664-72.

29. Walker AK, Spiller KJ, Ge G, Zheng A, Xu Y, Zhou $M$, et al. Functional recovery in new mouse models of ALS/FTLD after clearance of pathological cytoplasmic TDP-43. Acta neuropathologica. 2015.

30. Aggad D, Veriepe J, Tauffenberger A, Parker JA. TDP-43 toxicity proceeds via calcium dysregulation and necrosis in aging Caenorhabditis elegans motor neurons. The Journal of neuroscience : the official journal of the Society for Neuroscience. 2014;34(36):12093103.

31. Chou CC, Alexeeva OM, Yamada S, Pribadi A, Zhang $Y$, Mo B, et al. PABPN1 suppresses TDP-43 toxicity in ALS disease models. Human molecular genetics. 2015.

32. Polymenidou $M$, Lagier-Tourenne $C$, Hutt KR, Bennett CF, Cleveland DW, Yeo GW. Misregulated RNA processing in amyotrophic lateral sclerosis. Brain research. 2012;1462:3-15.

33. Bilican B, Serio A, Barmada SJ, Nishimura AL, Sullivan GJ, Carrasco M, et al. Mutant induced pluripotent stem cell lines recapitulate aspects of TDP-43 proteinopathies and reveal cellspecific vulnerability. Proceedings of the National Academy of Sciences of the United States of America. 2012;109(15):5803-8.

34. Herman AM, Khandelwal PJ, Rebeck GW, Moussa CE. Wild type TDP-43 induces neuroinflammation and alters APP metabolism in lentiviral gene transfer models. Experimental neurology. 2012;235(1):297-305.

35. Mosca L, Lunetta C, Tarlarini C, Avemaria F, Maestri E, Melazzini M, et al. Wide phenotypic spectrum of the TARDBP gene: homozygosity of $\mathrm{A} 382 \mathrm{~T}$ mutation in a patient presenting with amyotrophic lateral sclerosis, Parkinson's disease, and frontotemporal lobar degeneration, and in neurologically healthy subject. Neurobiology of aging. 2012;33(8):1846 e1-4.

36. Okamoto K, Amari M, Fujita Y, Makioka K, Fukuda T, Suzuki K, et al. Cytoplasmic TDP-43 accumulation in cells of the adrenal medulla in individuals with or without amyotrophic lateral sclerosis. Neuropathology : official journal of the Japanese Society of Neuropathology. 2014;34(6):535-40.

37. Johansson AS, Vestling M, Zetterstrom $P$, Lang $L$, Leinartaite $L$, Karlstrom $M$, et al. Cytotoxicity of superoxide dismutase 1 in cultured cells is linked to Zn2+ chelation. PloS one. 2012;7(4):e36104.

38. Mulligan VK, Kerman A, Laister RC, Sharda PR, Arslan PE, Chakrabartty A. Early steps in oxidation-induced SOD1 misfolding: implications for non-amyloid protein aggregation in familial ALS. Journal of molecular biology. 2012;421(45):631-52.

39. Brotherton TE, Li Y, Cooper D, Gearing M, Julien JP, Rothstein JD, et al. Localization of a toxic form of superoxide dismutase 1 protein to pathologically 
affected tissues in familial ALS. Proceedings of the National Academy of Sciences of the United States of America. 2012;109(14):5505-10.

40. Mera-Adasme R, Mendizabal F, Gonzalez M, Miranda-Rojas S, Olea-Azar C, Sundholm D. Computational studies of the metal-binding site of the wild-type and the H46R mutant of the copper, zinc superoxide dismutase. Inorganic chemistry. 2012;51(10):5561-8.

41. Pan L, Yoshii Y, Otomo A, Ogawa H, Iwasaki $Y$, Shang HF, et al. Different human copper-zinc superoxide dismutase mutants, SOD1G93A and SOD1H46R, exert distinct harmful effects on gross phenotype in mice. PloS one. 2012;7(3):e33409.

42. Guareschi S, Cova E, Cereda C, Ceroni M, Donetti E, Bosco DA, et al. An over-oxidized form of superoxide dismutase found in sporadic amyotrophic lateral sclerosis with bulbar onset shares a toxic mechanism with mutant SOD1. Proceedings of the National Academy of Sciences of the United States of America. 2012;109(13):5074-9.

43. Shan X, Vocadlo DJ, Krieger C. Reduced protein $\mathrm{O}$-glycosylation in the nervous system of the mutant SOD1 transgenic mouse model of amyotrophic lateral sclerosis. Neuroscience letters. 2012;516(2):296-301.

44. Alexander GM, Erwin KL, Byers N, Deitch JS, Augelli BJ, Blankenhorn EP, et al. Effect of transgene copy number on survival in the G93A SOD1 transgenic mouse model of ALS. Brain research Molecular brain research. 2004;130(12):7-15.

45. Drechsel DA, Estevez AG, Barbeito L, Beckman JS. Nitric oxide-mediated oxidative damage and the progressive demise of motor neurons in ALS. Neurotoxicity research. 2012;22(4):251-64.

46. Pokrishevsky E, Grad LI, Yousefi M, Wang J, Mackenzie IR, Cashman NR. Aberrant localization of FUS and TDP43 is associated with misfolding of SOD1 in amyotrophic lateral sclerosis. PloS one. 2012;7(4):e35050.

47. Kanouchi T, Ohkubo T, Yokota T. Can regional spreading of amyotrophic lateral sclerosis motor symptoms be explained by prionlike propagation? Journal of neurology, neurosurgery, and psychiatry. 2012;83(7):739-45.

48. Farg MA, Soo KY, Walker AK, Pham H, Orian $J$, Horne MK, et al. Mutant FUS induces endoplasmic reticulum stress in amyotrophic lateral sclerosis and interacts with protein disulfide-isomerase. Neurobiology of aging. 2012;33(12):2855-68.

49. Thau N, Jungnickel J, Knippenberg S, Ratzka A, Dengler $\mathrm{R}$, Petri $\mathrm{S}$, et al. Prolonged survival and milder impairment of motor function in the SOD1 ALS mouse model devoid of fibroblast growth factor 2. Neurobiology of disease. 2012;47(2):24857.

50. Yu Y, Reed R. FUS functions in coupling transcription to splicing by mediating an interaction between RNAP II and U1 snRNP. Proceedings of the National Academy of Sciences of the United States of America. 2015;112(28):8608-13.

51. Sama RR, Ward CL, Bosco DA. Functions of FUS/TLS from DNA repair to stress response: implications for ALS. ASN neuro. 2014;6(4).

52. Zhou Y, Liu S, Ozturk A, Hicks GG. FUS-regulated RNA metabolism and DNA damage repair: Implications for amyotrophic lateral sclerosis and frontotemporal dementia pathogenesis. Rare diseases. 2014;2:e29515.

53. Tarlarini C, Lunetta C, Mosca L, Avemaria F, Riva N, Mantero $V$, et al. Novel FUS mutations identified through molecular screening in a large cohort of familial and sporadic amyotrophic lateral sclerosis. European journal of neurology : the official journal of the European Federation of Neurological Societies. 2015.

54. Yang L, Zhang J, Kamelgarn M, Niu C, Gal J, Gong W, et al. Subcellular localization and RNAs determine FUS architecture in different cellular compartments. Human molecular genetics. 2015.

55. Takanashi K, Yamaguchi A. Aggregation of ALS-linked FUS mutant sequesters RNA binding proteins and impairs RNA granules formation. Biochemical and biophysical research communications. 2014;452(3):600-7.

56. Schwartz JC, Podell ER, Han SS, Berry JD, Eggan $\mathrm{KC}$, Cech TR. FUS is sequestered in nuclear aggregates in ALS patient fibroblasts. Molecular biology of the cell. 2014;25(17):2571-8.

57. Xia R, Liu Y, Yang L, Gal J, Zhu H, Jia J. Motor neuron apoptosis and neuromuscular junction perturbation are prominent features in a Drosophila model of Fus-mediated ALS. Molecular neurodegeneration. 2012;7:10.

58. Kino Y, Washizu C, Kurosawa M, Yamada M, 
Miyazaki $\mathrm{H}$, Akagi T, et al. FUS/TLS deficiency

causes behavioral and pathological

abnormalities distinct from amyotrophic

lateral sclerosis. Acta neuropathologica

communications. 2015;3:24.

59. Sephton CF, Tang AA, Kulkarni A, West J, Brooks $M$, Stubblefield JJ, et al. Activity-dependent FUS dysregulation disrupts synaptic homeostasis. Proceedings of the National Academy of Sciences of the United States of America. 2014; 111(44):E4769-78.

60. Lenzi J, De Santis R, de Turris V, Morlando M, Laneve $\mathrm{P}$, Calvo $\mathrm{A}$, et al. ALS mutant FUS proteins are recruited into stress granules in induced pluripotent stem cell-derived motoneurons. Disease models \& mechanisms. 2015;8(7):755-66.

61. Deng Q, Holler CJ, Taylor G, Hudson KF, Watkins $W$, Gearing $M$, et al. FUS is phosphorylated by DNA-PK and accumulates in the cytoplasm after DNA damage. The Journal of neuroscience : the official journal of the Society for Neuroscience. 2014;34(23):7802-13.

62. Suzuki H, Matsuoka M. Overexpression of nuclear FUS induces neuronal cell death. Neuroscience. 2015;287:113-24.

63. Lee $\mathrm{S}$, Kim HJ. Prion-like Mechanism in Amyotrophic Lateral Sclerosis: are Protein Aggregates the Key? Experimental neurobiology. 2015;24(1):1-7.

64. Maniecka Z, Polymenidou M. From nucleation to widespread propagation: A prion-like concept for ALS. Virus research. 2015;207:94-105.

65. Verma A. Protein aggregates and regional disease spread in ALS is reminiscent of prion-like pathogenesis. Neurology India. 2013;61(2):10710.

66. Li YR, King OD, Shorter J, Gitler AD. Stress granules as crucibles of ALS pathogenesis. The Journal of cell biology. 2013;201(3):361-72.

67. Patel AN, Sampson JB. Cognitive Profile of C9orf72 in Frontotemporal Dementia and Amyotrophic Lateral Sclerosis. Current neurology and neuroscience reports. 2015;15(9):582.

68. Cooper-Knock J, Higginbottom A, Stopford MJ, Highley JR, Ince PG, Wharton SB, et al. Antisense RNA foci in the motor neurons of C9ORF72-ALS patients are associated with TDP-43 proteinopathy. Acta neuropathologica. 2015;130(1):63-75.

69. Majounie E, Renton AE, Mok K, Dopper EG,
Waite A, Rollinson S, et al. Frequency of the C9orf72 hexanucleotide repeat expansion in patients with amyotrophic lateral sclerosis and frontotemporal dementia: a cross-sectional study. The Lancet Neurology. 2012;11(4):323-30.

70. Millecamps S, Boillee S, Le Ber I, Seilhean D, Teyssou E, Giraudeau M, et al. Phenotype difference between ALS patients with expanded repeats in C9ORF72 and patients with mutations in other ALS-related genes. Journal of medical genetics. 2012;49(4):258-63.

71. Sabatelli $M$, Conforti $F L$, Zollino $M$, Mora $\mathrm{G}$, Monsurro MR, Volanti P, et al. C9ORF72 hexanucleotide repeat expansions in the Italian sporadic ALS population. Neurobiology of aging. 2012;33(8):1848 e15-20.

72. Mok KY, Koutsis G, Schottlaender LV, Polke J, Panas $M$, Houlden $H$. High frequency of the expanded C9ORF72 hexanucleotide repeat in familial and sporadic Greek ALS patients. Neurobiology of aging. 2012;33(8):1851 e1-5.

73. Ozoguz A, Uyan O, Birdal G, Iskender C, Kartal E, Lahut $S$, et al. The distinct genetic pattern of ALS in Turkey and novel mutations. Neurobiology of aging. 2015;36(4):1764 e9-18.

74. Vrabec K, Koritnik B, Leonardis L, DolencGroselj L, Zidar J, Smith B, et al. Genetic analysis of amyotrophic lateral sclerosis in the Slovenian population. Neurobiology of aging. 2015;36(3):1601 e17-20.

75. Abramycheva NY, Lysogorskaia EV, Stepanova MS, Zakharova MN, Kovrazhkina EA, Razinskaya OD, et al. C9ORF72 hexanucleotide repeat expansion in ALS patients from the Central European Russia population. Neurobiology of aging. 2015.

76. He J, Tang L, Benyamin B, Shah S, Hemani G, Liu R, et al. C9orf72 hexanucleotide repeat expansions in Chinese sporadic amyotrophic lateral sclerosis. Neurobiology of aging. 2015;36(9):2660 e1-8.

77. Wang $C$, Chen Z, Yang F, Jiao B, Peng $H$, Shi $Y$, et al. Analysis of the GGGGCC Repeat Expansions of the C9orf72 Gene in SCA3/MJD Patients from China. PloS one. 2015;10(6):e0130336.

78. Rademakers R. C9orf72 repeat expansions in patients with ALS and FTD. The Lancet Neurology. 2012;11(4):297-8.

79. Cooper-Knock J, Bury JJ, Heath PR, Wyles M, Higginbottom A, Gelsthorpe C, et al. C9ORF72 GGGGCC Expanded Repeats Produce Splicing 
Dysregulation which Correlates with Disease Severity in Amyotrophic Lateral Sclerosis. PloS one. 2015;10(5):e0127376.

80. Xi Z, Zhang M, Bruni AC, Maletta RG, Colao R, Fratta $\mathrm{P}$, et al. The $\mathrm{C} 9$ orf72 repeat expansion itself is methylated in ALS and FTLD patients. Acta neuropathologica. 2015;129(5):715-27.

81. Russ J, Liu EY, Wu K, Neal D, Suh E, Irwin DJ, et al. Hypermethylation of repeat expanded C9orf72 is a clinical and molecular disease modifier. Acta neuropathologica. 2015;129(1):39-52.

82. Hukema RK, Riemslagh FW, Melhem S, van der Linde HC, Severijnen LA, Edbauer D, et al. A new inducible transgenic mouse model for C9orf72associated GGGGCC repeat expansion supports a gain-of-function mechanism in C9orf72associated ALS and FTD. Acta neuropathologica communications. 2014;2:166.

83. Mizielinska S, Isaacs AM. C9orf72 amyotrophic lateral sclerosis and frontotemporal dementia: gain or loss of function? Current opinion in neurology. 2014;27(5):515-23.

84. Cooper-Knock J, Kirby J, Highley R, Shaw PJ. The Spectrum of C9orf72-mediated Neurodegeneration and Amyotrophic Lateral Sclerosis. Neurotherapeutics : the journal of the American Society for Experimental NeuroTherapeutics. 2015;12(2):326-39.

85. Mendez EF, Sattler R. Biomarker development for C9orf72 repeat expansion in ALS. Brain research. 2015;1607:26-35.

86. Tokutake Y, Gushima K, Miyazaki H, Shimosato T, Yonekura S. ALS-associated P56S-VAPB mutation restrains 3T3-L1 preadipocyte differentiation. Biochemical and biophysical research communications. 2015;460(3):831-7.

87. Stoica R, De Vos KJ, Paillusson S, Mueller S, Sancho RM, Lau KF, et al. ER-mitochondria associations are regulated by the VAPB-PTPIP51 interaction and are disrupted by ALS/FTDassociated TDP-43. Nature communications. 2014;5:3996.

88. Kuijpers $M$, van Dis V, Haasdijk ED, Harterink M, Vocking K, Post JA, et al. Amyotrophic lateral sclerosis (ALS)-associated VAPB-P56S inclusions represent an ER quality control compartment. Acta neuropathologica communications. 2013;1:24.

89. Moumen A, Virard I, Raoul C. Accumulation of wildtype and ALS-linked mutated VAPB impairs activity of the proteasome. PloS one. 2011;6(10):e26066.

90. Suzuki H, Kanekura K, Levine TP, Kohno K, Olkkonen VM, Aiso S, et al. ALS-linked P56S-VAPB, an aggregated loss-of-function mutant of VAPB, predisposes motor neurons to ER stress-related death by inducing aggregation of co-expressed wild-type VAPB. Journal of neurochemistry. 2009;108(4):973-85.

91. Tokutake $Y$, Yamada $K$, Ohata $M$, Obayashi $Y$, Tsuchiya M, Yonekura S. ALS-Linked P56S-VAPB Mutation Impairs the Formation of Multinuclear Myotube in C2C12 Cells. International journal of molecular sciences. 2015;16(8):18628-41.

92. Qiu L, Qiao T, Beers M, Tan W, Wang H, Yang B, et al. Widespread aggregation of mutant VAPB associated with ALS does not cause motor neuron degeneration or modulate mutant SOD1 aggregation and toxicity in mice. Molecular neurodegeneration. 2013;8:1.

93. Aliaga L, Lai C, Yu J, Chub N, Shim H, Sun L, et al. Amyotrophic lateral sclerosis-related VAPB P56S mutation differentially affects the function and survival of corticospinal and spinal motor neurons. Human molecular genetics. 2013;22(21):4293-305.

94. Tran D, Chalhoub A, Schooley A, Zhang W, Ngsee $J K$. A mutation in VAPB that causes amyotrophic lateral sclerosis also causes a nuclear envelope defect. Journal of cell science. 2012;125(Pt 12):2831-6.

95. Genevini P, Papiani G, Ruggiano A, Cantoni $L$, Navone F, Borgese N. Amyotrophic lateral sclerosis-linked mutant VAPB inclusions do not interfere with protein degradation pathways or intracellular transport in a cultured cell model. PloS one. 2014;9(11):e113416.

96. Ingre C, Pinto S, Birve A, Press R, Danielsson O, de Carvalho $M$, et al. No association between VAPB mutations and familial or sporadic ALS in Sweden, Portugal and Iceland. Amyotrophic lateral sclerosis \& frontotemporal degeneration. 2013;14(7-8):620-7.

97. Maruyama $\mathrm{H}$, Morino $\mathrm{H}$, Ito $\mathrm{H}$, Izumi $\mathrm{Y}$, Kato $\mathrm{H}$, Watanabe $\mathrm{Y}$, et al. Mutations of optineurin in amyotrophic lateral sclerosis. Nature. 2010;465(7295):223-6.

98. Del Bo R, Tiloca C, Pensato V, Corrado L, Ratti A, Ticozzi $\mathrm{N}$, et al. Novel optineurin mutations in patients with familial and sporadic amyotrophic 
lateral sclerosis. Journal of neurology, neurosurgery, and psychiatry. 2011;82(11):123943.

99. Ying H, Yue BY. Optineurin: The autophagy connection. Experimental eye research. 2015.

100. 100. Wong YC, Holzbaur EL. Optineurin is an autophagy receptor for damaged mitochondria in parkin-mediated mitophagy that is disrupted by an ALS-linked mutation. Proceedings of the National Academy of Sciences of the United States of America. 2014;111(42):E4439-48.

101. Korac J, Schaeffer V, Kovacevic I, Clement AM, Jungblut $B$, Behl C, et al. Ubiquitin-independent function of optineurin in autophagic clearance of protein aggregates. Journal of cell science. 2013;126(Pt 2):580-92.

102. Paulus JD, Link BA. Loss of optineurin in vivo results in elevated cell death and alters axonal trafficking dynamics. PloS one. 2014;9(10):e109922.

103. Yamashita S, Kimura E, Tawara N, Sakaguchi $\mathrm{H}$, Nakama T, Maeda $\mathrm{Y}$, et al. Optineurin is potentially associated with TDP-43 and involved in the pathogenesis of inclusion body myositis. Neuropathology and applied neurobiology. 2013;39(4):406-16.

104. Kamada M, Izumi Y, Ayaki T, Nakamura $M$, Kagawa S, Kudo E, et al. Clinicopathologic features of autosomal recessive amyotrophic lateral sclerosis associated with optineurin mutation. Neuropathology : official journal of the Japanese Society of Neuropathology. 2014;34(1):64-70.

105. Akizuki $M$, Yamashita $H$, Uemura $K$, Maruyama $\mathrm{H}$, Kawakami $\mathrm{H}$, Ito $\mathrm{H}$, et al. Optineurin suppression causes neuronal cell death via NFkappaB pathway. Journal of neurochemistry. 2013;126(6):699-704.

106. lida A, Hosono N, Sano M, Kamei T, Oshima S, Tokuda T, et al. Novel deletion mutations of OPTN in amyotrophic lateral sclerosis in Japanese. Neurobiology of aging. 2012;33(8):1843 e19-24.

107. Johnson L, Miller JW, Gkazi AS, Vance C, Topp SD, Newhouse SJ, et al. Screening for OPTN mutations in a cohort of British amyotrophic lateral sclerosis patients. Neurobiology of aging. 2012;33(12):2948 e15-7.

108. van Blitterswijk $M$, van Vught $P W$, van Es MA, Schelhaas HJ, van der Kooi AJ, de
Visser M, et al. Novel optineurin mutations in sporadic amyotrophic lateral sclerosis patients. Neurobiology of aging. 2012;33(5):1016 e1-7.

109. Couthouis J, Hart MP, Erion R, King OD, Diaz $Z$, Nakaya T, et al. Evaluating the role of the FUS/TLS-related gene EWSR1 in amyotrophic lateral sclerosis. Human molecular genetics. 2012;21(13):2899-911.

110. King OD, Gitler AD, Shorter J. The tip of the iceberg: RNA-binding proteins with prion-like domains in neurodegenerative disease. Brain research. 2012;1462:61-80.

111. Hoell Jl, Larsson E, Runge S, Nusbaum JD, Duggimpudi S, Farazi TA, et al. RNA targets of wild-type and mutant FET family proteins. Nature structural \& molecular biology. 2011;18(12):142831.

112. Paronetto MP. Ewing sarcoma protein: a key player in human cancer. International journal of cell biology. 2013;2013:642853.

113. Salvi JS, Mekhail K. R-loops highlight the nucleus in ALS. Nucleus. 2015;6(1):23-9.

114. Gellera C, Ticozzi N, Pensato V, Nanetti L, Castucci A, Castellotti B, et al. ATAXIN2 CAG-repeat length in Italian patients with amyotrophic lateral sclerosis: risk factor or variant phenotype? Implication for genetic testing and counseling. Neurobiology of aging. 2012;33(8):1847 e15-21.

115. Borghero G, Pugliatti M, Marrosu F, Marrosu MG, Murru MR, Floris G, et al. ATXN2 is a modifier of phenotype in ALS patients of Sardinian ancestry. Neurobiology of aging. 2015.

116. Modgil S, Lahiri DK, Sharma VL, Anand A. Role of early life exposure and environment on neurodegeneration: implications on brain disorders. Translational neurodegeneration. 2014;3:9.

117. Al-Chalabi A, Kwak S, Mehler M, Rouleau $G$, Siddique T, Strong M, et al. Genetic and epigenetic studies of amyotrophic lateral sclerosis. Amyotrophic lateral sclerosis \& frontotemporal degeneration. 2013;14 Suppl 1:44-52.

118. Migliore L, Coppede F. Genetics, environmental factors and the emerging role of epigenetics in neurodegenerative diseases. Mutation research. 2009;667(1-2):82-97.

119. Nwaobi SE, Lin E, Peramsetty SR, Olsen ML. DNA methylation functions as a critical regulator 
of Kir4.1 expression during CNS development. Glia. 2014;62(3):411-27.

120. Chestnut BA, Chang Q, Price A, Lesuisse $C$, Wong $M$, Martin LJ. Epigenetic regulation of motor neuron cell death through DNA methylation. The Journal of neuroscience : the official journal of the Society for Neuroscience. 2011;31(46):16619-36.

121. Su XW, Broach JR, Connor JR, Gerhard GS, Simmons Z. Genetic heterogeneity of amyotrophic lateral sclerosis: implications for clinical practice and research. Muscle \& nerve. 2014;49(6):786-803.

122. Kleopa KA, Sherman M, Neal B, Romano GJ, Heiman-Patterson T. Bipap improves survival and rate of pulmonary function decline in patients with ALS. Journal of the neurological sciences. 1999;164(1):82-8.

123. Doble A. The pharmacology and mechanism of action of riluzole. Neurology. 1996;47(6 Suppl 4):S233-41.

124. Miller RG, Mitchell JD, Lyon M, Moore $\mathrm{DH}$. Riluzole for amyotrophic lateral sclerosis (ALS)/motor neuron disease (MND). The Cochrane database of systematic reviews. 2007(1):CD001447.

125. Rosen H. Dextromethorphan/quinidine sulfate for pseudobulbar affect. Drugs of today. 2008;44(9):661-8.

126. Gredal O, Werdelin L, Bak S, Christensen PB, Boysen G, Kristensen MO, et al. A clinical trial of dextromethorphan in amyotrophic lateral sclerosis. Acta neurologica Scandinavica. 1997;96(1):8-13.

127. Hollander D, Pradas J, Kaplan R, McLeod HL, Evans WE, Munsat TL. High-dose dextromethorphan in amyotrophic lateral sclerosis: phase I safety and pharmacokinetic studies. Annals of neurology. 1994;36(6):920-4.

128. Pioro EP, Brooks BR, Cummings J, Schiffer $R$, Thisted RA, Wynn D, et al. Dextromethorphan plus ultra low-dose quinidine reduces pseudobulbar affect. Annals of neurology. 2010;68(5):693-702.

129. Garnock-Jones KP. Dextromethorphan/ quinidine: in pseudobulbar affect. CNS drugs. 2011;25(5):435-45.

130. Patatanian E, Casselman J.

Dextromethorphan/quinidine for the treatment of pseudobulbar affect. The Consultant pharmacist : the journal of the American Society of Consultant Pharmacists. 2014;29(4):264-9.

131. Pioro EP. Review of Dextromethorphan $20 \mathrm{mg} /$ Quinidine $10 \mathrm{mg}$ (NUEDEXTA((R))) for Pseudobulbar Affect. Neurology and therapy. 2014;3(1):15-28.

132. Restivo DA, Casabona A, Nicotra A, Zappia M, Elia M, Romano MC, et al. ALS dysphagia pathophysiology: differential botulinum toxin response. Neurology. 2013;80(7):616-20.

133. Manrique D. Application of botulinum toxin to reduce the saliva in patients with amyotrophic lateral sclerosis. Brazilian journal of otorhinolaryngology. 2005;71(5):566-9.

134. Verma A, Steele J. Botulinum toxin improves sialorrhea and quality of living in bulbar amyotrophic lateral sclerosis. Muscle \& nerve. 2006;34(2):235-7.

135. Bello-Haas VD, Florence JM, Kloos AD, Scheirbecker J, Lopate G, Hayes SM, et al. A randomized controlled trial of resistance exercise in individuals with ALS. Neurology. 2007;68(23):2003-7.

136. Dalbello-Haas V, Florence JM, Krivickas LS. Therapeutic exercise for people with amyotrophic lateral sclerosis or motor neuron disease. The Cochrane database of systematic reviews. 2008(2):CD005229.

137. Dal Bello-Haas V, Florence JM. Therapeutic exercise for people with amyotrophic lateral sclerosis or motor neuron disease. The Cochrane database of systematic reviews. 2013;5:CD005229.

138. Phukan J. Arimoclomol, a coinducer of heat shock proteins for the potential treatment of amyotrophic lateral sclerosis. IDrugs : the investigational drugs journal. 2010;13(7):482-96.

139. Cudkowicz ME, Shefner JM, Simpson E, Grasso D, Yu H, Zhang H, et al. Arimoclomol at dosages up to $300 \mathrm{mg} /$ day is well tolerated and safe in amyotrophic lateral sclerosis. Muscle \& nerve. 2008;38(1):837-44.

140. Lee S, Kim Y, Li E, Park S. Ghrelin protects spinal cord motoneurons against chronic glutamate excitotoxicity by inhibiting microglial activation. The Korean journal of physiology \& pharmacology : official journal of the Korean Physiological Society and the Korean Society of Pharmacology. 2012;16(1):43-8.

141. Miller RG, Shepherd R, Dao H, Khramstov 
A, Mendoza M, Graves J, et al. Controlled trial of nimodipine in amyotrophic lateral sclerosis.

Neuromuscular disorders : NMD. 1996;6(2):101-4.

142. Kriz J, Gowing G, Julien JP. Efficient threedrug cocktail for disease induced by mutant superoxide dismutase. Annals of neurology. 2003;53(4):429-36.

143. Kaufmann P, Thompson JL, Levy G, Buchsbaum R, Shefner J, Krivickas LS, et al. Phase II trial of CoQ10 for ALS finds insufficient evidence to justify phase III. Annals of neurology. 2009;66(2):235-44.

144. Forlenza OV, De-Paula VJ, Diniz BS.

Neuroprotective effects of lithium: implications for the treatment of Alzheimer's disease and related neurodegenerative disorders. ACS chemical neuroscience. 2014;5(6):443-50.

145. Gamez J, Salvado M, Martinez de la Ossa A, Badia M. Lithium for treatment of amyotrophic lateral sclerosis: much ado about nothing. Neurologia. 2013.

146. Group UK-LS, Morrison KE, Dhariwal S, Hornabrook R, Savage L, Burn DJ, et al. Lithium in patients with amyotrophic lateral sclerosis (LiCALS): a phase 3 multicentre, randomised, double-blind, placebo-controlled trial. The Lancet Neurology. 2013;12(4):339-45.

147. Verstraete $E$, Veldink JH, Huisman $\mathrm{MH}$, Draak T, Uijtendaal EV, van der Kooi AJ, et al. Lithium lacks effect on survival in amyotrophic lateral sclerosis: a phase llb randomised sequential trial. Journal of neurology, neurosurgery, and psychiatry. 2012;83(5):557-64.

148. Yanez M, Matias-Guiu J, Arranz-Tagarro JA, Galan L, Vina D, Gomez-Pinedo U, et al. The neuroprotection exerted by memantine, minocycline and lithium, against neurotoxicity of CSF from patients with amyotrophic lateral sclerosis, is antagonized by riluzole. Neurodegenerative diseases. 2014;13(2-3):171-9.

149. Elewa HF, Hilali $\mathrm{H}$, Hess DC, Machado LS, Fagan SC. Minocycline for short-term neuroprotection. Pharmacotherapy. 2006;26(4):515-21.

150. Festoff BW, Ameenuddin S, Arnold PM, Wong A, Santacruz KS, Citron BA. Minocycline neuroprotects, reduces microgliosis, and inhibits caspase protease expression early after spinal cord injury. Journal of neurochemistry. 2006;97(5):1314-26.
151. Pontieri FE, Ricci A, Pellicano C, Benincasa D, Buttarelli FR. Minocycline in amyotrophic lateral sclerosis: a pilot study. Neurological sciences : official journal of the Italian Neurological Society and of the Italian Society of Clinical Neurophysiology. 2005;26(4):285-7.

152. Khiat A, D'Amour M, Souchon F, Boulanger Y. MRS study of the effects of minocycline on markers of neuronal and microglial integrity in ALS. Magnetic resonance imaging. 2010;28(10):1456-60.

153. Gordon PH, Moore DH, Miller RG, Florence JM, Verheijde JL, Doorish C, et al. Efficacy of minocycline in patients with amyotrophic lateral sclerosis: a phase III randomised trial. The Lancet Neurology. 2007;6(12):1045-53.

154. Lou JS, Moore D, Gordon PH, Miller R. Correlates of quality of life in ALS: Lessons from the minocycline study. Amyotrophic lateral sclerosis : official publication of the World Federation of Neurology Research Group on Motor Neuron Diseases. 2010;11(1-2):116-21.

155. Koh SH, Kim Y, Kim HY, Cho GW, Kim KS, Kim SH. Recombinant human erythropoietin suppresses symptom onset and progression of G93A-SOD1 mouse model of ALS by preventing motor neuron death and inflammation. The European journal of neuroscience. 2007;25(7):1923-30.

156. Naganska E, Taraszewska A, Matyja E, Grieb $P$, Rafalowska J. Neuroprotective effect of erythropoietin in amyotrophic lateral sclerosis (ALS) model in vitro. Ultrastructural study. Folia neuropathologica / Association of Polish Neuropathologists and Medical Research Centre, Polish Academy of Sciences. 2010;48(1):35-44.

157. Noh MY, Cho KA, Kim H, Kim SM, Kim $\mathrm{SH}$. Erythropoietin modulates the immuneinflammatory response of a SOD1 (G93A) transgenic mouse model of amyotrophic lateral sclerosis (ALS). Neuroscience letters. 2014;574:538.

158. Widl K, Brettschneider J, Schattauer D, Sussmuth S, Huber R, Ludolph AC, et al. Erythropoietin in cerebrospinal fluid: agerelated reference values and relevance in neurological disease. Neurochemical research. 2007;32(7):1163-8.

159. Kim HY, Moon C, Kim KS, Oh KW, Oh SI, Kim $J$, et al. Recombinant human erythropoietin 
in amyotrophic lateral sclerosis: a pilot study of safety and feasibility. Journal of clinical neurology. 2014;10(4):342-7.

160. Lauria G, Campanella A, Filippini G, Martini

A, Penza P, Maggi L, et al. Erythropoietin in amyotrophic lateral sclerosis: a pilot, randomized, double-blind, placebo-controlled study of safety and tolerability. Amyotrophic lateral sclerosis : official publication of the World Federation of Neurology Research Group on Motor Neuron Diseases. 2009;10(5-6):410-5.

161. Lauria G, Dalla Bella E, Antonini G, Borghero G, Capasso M, Caponnetto C, et al. Erythropoietin in amyotrophic lateral sclerosis: a multicentre, randomised, double blind, placebo controlled, phase III study. Journal of neurology, neurosurgery, and psychiatry. 2015;86(8):879-86.

162. Blanquer M, Moraleda JM, Iniesta F, GomezEspuch J, Meca-Lallana J, Villaverde R, et al. Neurotrophic bone marrow cellular nests prevent spinal motoneuron degeneration in amyotrophic lateral sclerosis patients: a pilot safety study. Stem cells. 2012;30(6):1277-85.

163. Glass JD, Boulis NM, Johe K, Rutkove SB, Federici T, Polak $M$, et al. Lumbar intraspinal injection of neural stem cells in patients with amyotrophic lateral sclerosis: results of a phase I trial in 12 patients. Stem cells. 2012;30(6):114451.

164. Jablonski MR, Jacob DA, Campos C, Miller DS, Maragakis NJ, Pasinelli $P$, et al. Selective increase of two $A B C$ drug efflux transporters at the blood-spinal cord barrier suggests induced pharmacoresistance in ALS. Neurobiology of disease. 2012;47(2):194-200. 